\title{
Testing the breeding strategy of Hungarian Bronze turkey strains for maintaining genetic diversity with microsatellites
}

\author{
Szilvia Kusza', Sándor Mihók², Levente Czeglédi², András Jávor' and Mariann Árnyasi' \\ 'Institute of Sámuel Diószegi Agrarinnovation, ${ }^{2}$ Institute of Animal Science and Protection of Biodiversity, Faculty \\ of Agricultural and Food Science and Environmental Management, Centre for Agricultural and Applied Economic \\ Sciences, Debrecen, Hungary
}

\begin{abstract}
The aim of the study was to provide information on the genetic variability of the Hungarian Bronze turkey gene reserve population and its difference from the Broad-breasted turkey, and offer guidance and proposals for its future conservation strategies. Altogether, 239 Hungarian Bronze turkeys from 10 strains and 13 Broad-breasted turkeys as a control population were genotyped for 15 microsatellites. All loci were polymorphic with the average number of alleles per locus $3.20 \pm 1.146$ in the Hungarian Bronze turkey. The mean expected $\left(\mathrm{H}_{\text {exp }}\right)$ and observed heterozygosity $\left(\mathrm{H}_{\text {obs }}\right)$ were not different ( 0.392 and 0.376 , respectively) in the overall population, and similar values were obtained for hens and bucks and among hen strains. Inbreeding coefficient $\left(\mathrm{F}_{15}\right)$ and Shannon index (I) indicated that there was low inbreeding within hens and bucks. Our results confirm that the genetic diversity in the Hungarian Bronze turkey population has been preserved by the rotational mating system. Differences between the Hungarian Bronze turkey and the Broad-breasted turkey populations were determined. Nei's unbiased values clearly indicated that the two populations are highly genetically differentiated.
\end{abstract}

Keywords: Hungarian Bronze turkey, Broad-breasted turkey, genetic diversity, microsatellite, conservation of gene reserve population

\section{Zusammenfassung}

\section{Prüfung der Zuchtstrategie mittels Mikrosatelliten zur Erhaltung der genetischen Vielfalt von ungarischen Bronzeputen}

Das Ziel der Studie war es, Informationen über die genetische Vielfalt der ungarischen Bronzeputen als Genreserve im Vergleich zur breitbrüstigen Pute für zukünftige Zuchtstrategien zu erhalten. Insgesamt wurden 239 ungarische Bronzeputen aus 10 Linien und 13 breitbrüstigePuten als Kontrollgruppe für 15 Mikrosatelliten genotypisiert. Alle Loci waren polymorph mit einer durchschnittlichen Anzahl von 3,20 \pm 1,146 Allelen pro Locus bei der ungarischen Bronzepute. Die mittlere erwartete $\left(\mathrm{H}_{\text {exp }}\right)$ und beobachtete $\left(\mathrm{H}_{\text {obs }}\right)$ Heterozygosität unterschieden sich nicht (0,392 bzw. 0,376). Ähnliche Werte wurden für Puten und Puter sowie Putenlinien gefunden. Inzuchtkoeffizient (FIS) und Shannon Index (I) für 
Puten und Puter waren niedrig. Es bestätigte sich, dass durch das Rotationspaarungssystem die genetische Vielfalt erhalten wurde. Zwischen den ungarischen Bronzeputen und den breitbrüstigen Puten bestehen deutliche genetische Unterschiede.

Schlüsselwörter: Hungarian Bronze turkey, Broad-breasted turkey, genetic diversity, microsatellite, conservation of gene reserve population

\section{Introduction}

The turkey (Meleagris gallopavo) is the second most important poultry species agriculturally after the chicken. Most literature about poultry concerns genetic background and structure of the chicken genome; however, as the importance of the turkey grows, so biological information about this species must increase. According to the American Poultry Association, turkey variants are considered a single breed (Kamara et al. 2007). Knowledge of the genetic diversity of turkey populations, strains and breeds is important for the diversity of turkey varieties. This essential genetic resource could help breeders improve their birds' health and vigour or respond to changing environmental conditions, production systems and consumer needs (Christman \& Hawes 1999).

The Meleagris genus originates in America; however, the turkey (Meleagris gallopavo) has been bred in Hungary since the end of 16th century (Mihók 2000). One native Hungarian turkey breed is the Hungarian Bronze turkey. The Black turkey had previously been common, but is now only kept on small farms. Its population has decreased because of crossing with Bronze and other breeds at the beginning of the previous century. The Bronze turkey has adapted to local conditions to become a native breed. There is another native turkey type - the Hungarian Copper turkey - that is kept in the south of the country (Szalay et al. 2009). Performance and meat production are similar for all three types; therefore, it remains a question whether they are different breeds or only colour varieties. Some meat quality parameters of the Hungarian Bronze turkey, such as water-holding capacity, consistency and tenderness, are better and production level is usually less than that of the intensive breeds (Mihók et al. 1999). The adult weight of a male is $10-12 \mathrm{~kg}$ and $5-7 \mathrm{~kg}$ for females. The main advantage of this breed is its excellent feed-seeking ability and vitality. In the 1960s, the number of stocks decreased as intensive production systems became widespread (Mihók 2000). The Broad-breasted Bronze turkey is an improved type of Bronze turkey bred in the USA. Adult males weigh $12-13 \mathrm{~kg}$ and females $7-9 \mathrm{~kg}$ with a broad breast and good carcass performance (Sütő 2006).

Considering that few data are available about native turkey types and their genetic backgrounds, the purpose of this work was to determine the genetic diversity of a Hungarian Bronze turkey gene reserve strains, evaluate the effectiveness of the present mating system to preserve genetic diversity and finally compare this native population to the Broad-breasted turkey breed using modern molecular genetics tools. 


\section{Material and methods}

Animals

The examined Hungarian Bronze turkey has been owned by the University of Debrecen, Hungary for more than 15 years in order to maintain a gene reserve population. In 1999, 12 unrelated strains were generated containing 14-16 hens and 3-4 tons per strain. To keep the genetic diversity the following breeding program has been used since 2000 . Hens in a given strain provide the next generation in the same strain, and the bucks will be the next generation of bucks of the neighbouring strain. In the reproduction cycle, animals mate at random within each strain. Hens lay 19 eggs on average and are kept for two years. Unfortunately, the number of animals in two strains decreased so much that these strains were divided out among the other strains over the past six years.

In this study, 239 Hungarian Bronze turkeys from 10 strains and 13 Broad-breasted turkeys as a control population were examined (Table 5). Blood samples were collected from both strains in 2007.

\section{DNA extraction and microsatellite analyses}

Genomic DNA from total blood was extracted using the Zsolnai \& Orbán (1999) procedure. Microsatellites were chosen based on their chromosomal location (Table 1).

Polymerase chain reactions (PCRs) were prepared in a total volume of $10 \mu$ containing $30 \mathrm{mM} \mathrm{MgCl}$, $2 \mathrm{mM}$ of each dNTP, $2.5 \mu \mathrm{M}$ of each primer, $5 \mathrm{U}$ Taq polymerase and 100$200 \mathrm{ng}$ genomic DNA. Amplifications were performed using a Perkin Elmer Gene Amp PCR System 9700 Thermocycler (Applied Biosystems, Foster City, CA, USA) and DNA Engine Peltier Thermal Cycle (Bio-Rad, USA). Running conditions consisted of $10 \mathrm{~min}$ at $95^{\circ} \mathrm{C}$ followed by 35 cycles of $15 \mathrm{~s}$ at $95^{\circ} \mathrm{C}, 30 \mathrm{~s}$ at $51-62^{\circ} \mathrm{C}$ (depending on the microsatellites, Table 1), $30 \mathrm{~s}$ at $73^{\circ} \mathrm{C}$ and a final extension step of $20 \mathrm{~min}$ at $73^{\circ} \mathrm{C}$. PCR products were run in two multiplexes and analysed using an ABI Prism 310 Genetic Analyser (Applied Biosystems, Foster City, CA, USA). The size of each fragment was determined relative to the LIZ 500 size standards (Applied Biosystems). GeneMapper 3.7 software (ABI; Perkin Elmer, Foster City, CA, USA) was used for genotype scoring.

\section{Statistical analysis}

Popgene version 1.31 software package was used for statistical analysis (Yeh \& Yong 1999). Population structure was analysed using Wright's fixation indexes (Weir \& Cockerham 1984). Expected $\left(\mathrm{H}_{\text {exp }}\right)$ and observed heterozygosity $\left(\mathrm{H}_{\text {obs }}\right)$ were computed using Levene (1949). The effective number of alleles $\left(\mathrm{N}_{\mathrm{e}}\right)$ was calculated by the Kimura \& Crow (1964) formula. Shannon index (I) was calculated to determine genetic diversity (Lewontin 1972). Based on microsatellite data, Nei's (1987) unbiased genetic distance was used for dendrogram construction according to the neighbour-joining algorithm. 
Table 1

Main characteristics of used primers

\begin{tabular}{|c|c|c|c|c|c|}
\hline Name & Chrom. & Primers $\left(5^{\prime}-3^{\prime}\right)$ & Temp., ${ }^{\circ} \mathrm{C}$ & Length, bp & Accession no. \\
\hline ADL0149 & M12 & $\begin{array}{l}\text { Forward: ATA GCA TAC ACC CAG CCA CC } \\
\text { Reverse: GAA TAA GAA TGT TNC CCT GC }\end{array}$ & 57 & $224-238$ & G01574 \\
\hline ADL0266 & M4 & $\begin{array}{l}\text { Forward: GTG GCA TTC AGG CAG AGC AG } \\
\text { Reverse: AAT GCA TTG CAG GAT GTA TG }\end{array}$ & 50 & $94-109$ & G01686 \\
\hline ADL0292 & M5 & $\begin{array}{l}\text { Forward: CCA AAT CAG GCA AAA CTT CT } \\
\text { Reverse: AAA TGG CCT AAG GAT GAG GA }\end{array}$ & 59 & 128 & G01710 \\
\hline ADL0293 & M12 & $\begin{array}{l}\text { Forward: GTA ATC TAG AAA CCC CAT CT } \\
\text { Reverse: ACA TAC CGC AGT CTT TGT TC }\end{array}$ & 50 & 99 & G01711 \\
\hline MCW0080 & M13 & $\begin{array}{l}\text { Forward: CCG TGC ATT CTT AAT TGA CAG } \\
\text { Reverse: GAA ATG GTA CAG TGC AGT TGG }\end{array}$ & 50 & $276-288$ & L40045 \\
\hline MNT106 & M18 & $\begin{array}{l}\text { Forward: TGC AGT GTG AAT ATT GGC TTG } \\
\text { Reverse: AAA TAA TGA AGA CAC CGA CAT TTT C }\end{array}$ & 58 & $158-168$ & AF540409 \\
\hline MNT162 & M6 & $\begin{array}{l}\text { Forward: AAA AAC CTG AAA ATG TAA ATC CA } \\
\text { Reverse: TTC AGA TCT TTT ATT TTT CGA AGC }\end{array}$ & 59 & $94-100$ & AY235131 \\
\hline MNT174 & M1 & $\begin{array}{l}\text { Forward: AAA ATT CAG TCC CCC AGA GG } \\
\text { Reverse: CTC AGG ATG CAA GCC TTC TC }\end{array}$ & 62 & 204-216 & AY235142 \\
\hline MNT192 & M26 & $\begin{array}{l}\text { Forward: ATT GGT CAG GGT GCC AAT AG } \\
\text { Reverse: AGC ACA TTG CAG TTG TTT GC }\end{array}$ & 62 & 203-219 & AY235160 \\
\hline MNT197 & M8 & $\begin{array}{l}\text { Forward: GCT TAC GGA GAT AAG AGC TTT GG } \\
\text { Reverse: CCA CAT TGC AGA GGG TCA C }\end{array}$ & 58 & $105-117$ & AY235165 \\
\hline MNT199 & M3 & $\begin{array}{l}\text { Forward: AGC TTC CTA TTC AAG AGT TTT GG } \\
\text { Reverse: AGT CCA AGA CCA GCC ACC AG }\end{array}$ & 58 & $136-150$ & AY235166 \\
\hline MNT214 & M4 & $\begin{array}{l}\text { Forward: GCC ATG AAT GTC AAA AGG AAC } \\
\text { Reverse: GGG TGA GCC TGG GTA GAA TG }\end{array}$ & 60 & $190-206$ & AY235179 \\
\hline MNT327 & M24 & $\begin{array}{l}\text { Forward: TTG TGT TAT GCA AGT AAA AGC ATC } \\
\text { Reverse: GGC TAA CCA GAG CTT CAT GC }\end{array}$ & 60 & $205-213$ & AY552897 \\
\hline MNT332 & M15 & $\begin{array}{l}\text { Forward: TTG GTC AAC ATT TGG AAG ACC } \\
\text { Reverse: ATT AGC TAA CAG CTG CAA AAT GG }\end{array}$ & 58 & $149-161$ & AY552902 \\
\hline MNT387 & M14 & $\begin{array}{l}\text { Forward: AAG CGT TCC ATC TGT TTT GG } \\
\text { Reverse: TTC CTA GCC TCT CAT CTG TGC }\end{array}$ & 56 & $130-135$ & AY552955 \\
\hline
\end{tabular}

\section{Results}

Genetic structure of the Hungarian Bronze turkey strains

Altogether, 48 alleles were detected on the 15 microsatellite loci. All loci were polymorphic with the number of alleles per locus $\left(\mathrm{N}_{\mathrm{a}}\right.$ ) varying from two (ADL0149, ADL0266, ADL0293, MCW0080) to six (MNT162). The average number of alleles per locus was $3.20 \pm 1.146$. The effective number of alleles per locus ranged from 1.062 (ADL0293) to 3.615 (MNT162) (Table 2). Rare alleles (with a frequency of less than 0.05 ) were found for 10 loci (Table 3 ). The rest of the allele frequencies are available from the authors on request.

Expected heterozygosity ranged from 0.059 (ADL0293) to 0.725 (MNT162) and the mean of $\mathrm{H}_{\exp }$ was $0.392 \pm 0.217$ among loci (Table 2).

The mean of Hobs was $0.376 \pm 0.224$ among loci, ranging between 0.000 (ADL0293) and 0.722 (MNT162). Higher $\mathrm{H}_{\text {exp }}$ than $\mathrm{H}_{\text {obs }}$ were obtained in case of nine microsatellites. $A$ significant deviation from the Hardy-Weinberg equilibrium was observed for only three microsatellites at $P<0.01$ (Table 2). The inbreeding coefficient $\left(\mathrm{F}_{\mathrm{IS}}\right)$ among loci varied from 1.000 (ADL0292) to -0.186 (MNT199) (Table 2). 
Table 2

Number of alleles, heterozygosity per locus and inbreeding coefficient in the Hungarian Bronze turkey strains

\begin{tabular}{lccccr}
\hline Locus & $\mathrm{N}_{\mathrm{a}}$ & $\mathrm{N}_{\mathrm{e}}$ & $\mathrm{H}_{\exp }$ & $\mathrm{H}_{\text {obs }}$ & \multicolumn{1}{c}{$\mathrm{F}_{\mathrm{IS}}$} \\
\hline ADL0149 & 2 & 1.385 & 0.279 & 0.312 & -0.124 \\
ADL0266 & 2 & 1.741 & 0.428 & 0.448 & -0.052 \\
ADL0292 & 3 & 1.147 & 0.128 & 0.130 & -0.013 \\
ADL0293* & 2 & 1.062 & 0.059 & 0.000 & 1.000 \\
MCW0080 & 2 & 1.097 & 0.089 & 0.093 & -0.049 \\
MNT106* & 3 & 2.356 & 0.577 & 0.552 & 0.042 \\
MNT162 & 6 & 3.615 & 0.725 & 0.722 & 0.002 \\
MNT174 & 3 & 2.794 & 0.645 & 0.632 & 0.016 \\
MNT192 & 5 & 2.778 & 0.642 & 0.565 & 0.117 \\
MNT197 & 4 & 1.691 & 0.410 & 0.392 & 0.041 \\
MNT199 & 3 & 2.395 & 0.584 & 0.691 & -0.186 \\
MNT214 & 4 & 1.733 & 0.424 & 0.369 & 0.127 \\
MNT327 & 3 & 1.313 & 0.239 & 0.212 & 0.108 \\
MNT332 & 3 & 1.252 & 0.202 & 0.211 & -0.049 \\
MNT387* & 3 & 1.808 & 0.448 & 0.316 & 0.293 \\
Mean & $3.200 \pm 1.146$ & $1.878 \pm 0.756$ & $0.392 \pm 0.217$ & $0.376 \pm 0.224$ & 0.037 \\
\hline
\end{tabular}

${ }^{*}$ significant deviation from Hardy-Weinberg equilibrium $(P<0.001), \quad N_{a}$ : observed number of alleles, $N_{e}$ : effective number of alleles, $\mathrm{H}_{\mathrm{ob}}$ : observed heterozygosity, $\mathrm{H}_{\text {exp }}$ : expected heterozygosity, $\mathrm{F}_{\mathrm{IS}}$ : inbreeding coefficient

\section{Genetic differentiation between Hungarian Bronze turkey hens and bucks}

The genetic structure of hens $(n=194)$ and bucks $(n=45)$ were analysed separately. From the examined 15 loci, 47 alleles were detected in hens and 43 in bucks. The same number of alleles was found in 11 loci in hens and bucks. Two more alleles were detected on locus MNT162 and MNT214: one (MNT327) when comparing hens to bucks and one (MNT387) when comparing bucks to hens. Each of those alleles, which were found only in hens or in bucks, had less than a 0.05 frequency in the overall population (Table 3).

Table 3

Frequency of rare alleles in the Hungarian Bronze turkey strains

\begin{tabular}{lcccc}
\hline Locus & Alleles & F in the whole strains & F in hens & F in bucks \\
\hline ADL0292 & 117 & 0.039 & 0.041 & 0.033 \\
ADL0293 & 131 & 0.029 & 0.030 & 0.022 \\
MCW0080 & 89 & 0.030 & 0.011 & 0.046 \\
MNT162 & 279 & 0.046 & 0.047 & \\
MNT192 & 86 & 0.003 & 0.003 & 0.033 \\
& 88 & 0.003 & 0.003 & 0.011 \\
MNT197 & 207 & 0.013 & 0.007 & 0.022 \\
MNT214 & 217 & 0.008 & 0.007 & 0.044 \\
MNT327 & 97 & 0.039 & 0.011 & 0.007 \\
MNT332 & 200 & 0.008 & 0.007 & 0.033 \\
MNT387 & 192 & 0.005 & 0.024 & 0.011 \\
\hline
\end{tabular}

F: allele frequency 
Mean of $\mathrm{N}_{a}$ was higher in hens than in bucks, however, the mean of $\mathrm{N}_{\mathrm{e}}$ was slightly higher in bucks than in hens (Table 4).

Table 4

Number of alleles, heterozygosity, inbreeding coefficient and Shannon index per hen and buck

\begin{tabular}{|c|c|c|c|c|c|c|}
\hline Population & $\mathrm{N}_{\mathrm{a}}$ & $\mathrm{N}_{\mathrm{e}}$ & $\mathrm{H}_{\exp }$ & $\mathrm{H}_{\text {obs }}$ & $F_{15}$ & 1 \\
\hline Hens & $3.133 \pm 1.187$ & $1.868 \pm 0.756$ & $0.389 \pm 0.218$ & $0.383 \pm 0.223$ & 0.011 & $0.667 \pm 0.366$ \\
\hline Bucks & $2.867 \pm 0.916$ & $1.896 \pm 0.724$ & $0.408 \pm 0.209$ & $0.354 \pm 0.231$ & 0.119 & $0.684 \pm 0.346$ \\
\hline
\end{tabular}

This might be the result of the lower number of bucks than hens. Significant deviation from the Hardy-Weinberg equilibrium was observed for three loci in bucks (MNT327 $[P<0.05]$, ADL0293 and MNT332 $[P<0.01]$ ), and for six loci in hens (ADL0149, MNT197 and MNT199 $[P<0.05]$ and ADL0293, MNT106 and MNT387 $[P<0.001])$.

Mean $\mathrm{H}_{\text {exp }}$ was higher than mean $\mathrm{H}_{\text {obs }}$ in both hens and bucks. $\mathrm{F}_{\text {Is }}$ and Shannon index indicated that there was a low inbreeding within hens and bucks (Table 4). Multilocus fixation index $\left(\mathrm{F}_{\mathrm{ST}}\right)$ indicated that around $0.4 \%$ of the total genetic variation could be explained by a sex difference; the remaining corresponded to differences among individuals. Nei's unbiased genetic distance value was low between hens and bucks (0.003).

\section{Genetic differentiation among the Hungarian Bronze turkey hen strains}

The genetic structure of the 10 strains was investigated separately and differentiation was determined among them. Three loci (ADL0292, ADL0293 and MNT332) were found to be not polymorphic in at least one strain. All hens were homozygous for one of these loci in strains 1, 3 and 5-8, two loci in strains 2, 9 and 10 and three loci in strain 4. The number of alleles per locus varied between one and five in the strains. The mean number of alleles per locus per strain ranged from $2.333 \pm 0.724$ (strain 9) to $2.600 \pm 0.828$ (strain 3). The examined hen strains had similar levels of allelic variations. $\mathrm{N}_{\mathrm{e}}$ ranged from $1.598 \pm 0.655$ (strain 1) to $1.934 \pm 0.753$ (strain 8) (Table 5).

Table 5

Number of alleles, heterozygosity and inbreeding coefficient and Shannon index per Hungarian Bronze turkey hen strain

\begin{tabular}{cccccccc}
\hline Strains & $\mathrm{N}$ & $\mathrm{N}_{\mathrm{a}}$ & $\mathrm{N}_{\mathrm{e}}$ & $\mathrm{H}_{\exp }$ & $\mathrm{H}_{\text {obs }}$ & $\mathrm{F}_{\text {Is }}$ & $\mathrm{I}$ \\
\hline 1 & 23 & $2.400 \pm 0.828$ & $1.598 \pm 0.655$ & $0.306 \pm 0.234$ & $0.342 \pm 0.272$ & -0.075 & $0.504 \pm 0.369$ \\
2 & 18 & $2.467 \pm 0.834$ & $1.664 \pm 0.575$ & $0.349 \pm 0.216$ & $0.364 \pm 0.233$ & -0.087 & $0.569 \pm 0.347$ \\
3 & 31 & $2.600 \pm 0.828$ & $1.807 \pm 0.667$ & $0.381 \pm 0.235$ & $0.385 \pm 0.254$ & -0.014 & $0.627 \pm 0.375$ \\
4 & 24 & $2.467 \pm 1.187$ & $1.779 \pm 0.828$ & $0.350 \pm 0.253$ & $0.358 \pm 0.267$ & -0.055 & $0.579 \pm 0.431$ \\
5 & 17 & $2.467 \pm 0.990$ & $1.643 \pm 0.552$ & $0.344 \pm 0.210$ & $0.311 \pm 0.210$ & 0.035 & $0.557 \pm 0.340$ \\
6 & 21 & $2.267 \pm 0.704$ & $1.828 \pm 0.655$ & $0.394 \pm 0.232$ & $0.396 \pm 0.281$ & -0.017 & $0.606 \pm 0.358$ \\
7 & 20 & $2.467 \pm 0.834$ & $1.764 \pm 0.607$ & $0.379 \pm 0.226$ & $0.429 \pm 0.262$ & -0.035 & $0.607 \pm 0.362$ \\
8 & 10 & $2.533 \pm 0.834$ & $1.934 \pm 0.753$ & $0.434 \pm 0.238$ & $0.458 \pm 0.252$ & -0.093 & $0.678 \pm 0.385$ \\
9 & 13 & $2.333 \pm 0.724$ & $1.720 \pm 0.573$ & $0.371 \pm 0.230$ & $0.396 \pm 0.309$ & -0.116 & $0.585 \pm 0.357$ \\
10 & 17 & $2.533 \pm 0.916$ & $1.907 \pm 0.736$ & $0.419 \pm 0.254$ & $0.431 \pm 0.291$ & -0.052 & $0.657 \pm 0.398$ \\
Mean & & $3.133 \pm 1.187$ & $1.868 \pm 0.756$ & $0.389 \pm 0.218$ & $0.383 \pm 0.223$ & -0.082 & $0.667 \pm 0.366$ \\
\hline
\end{tabular}

$\mathrm{N}$ : number of examined individuals, $\mathrm{N}_{\mathrm{a}}$ : observed number of alleles, $\mathrm{N}_{\mathrm{e}}$ : effective number of alleles, $\mathrm{H}_{\mathrm{ob}}$ : observed heterozygosity, $\mathrm{H}_{\text {exp }}$ : expected heterozygosity, $\mathrm{F}_{15}$ : inbreeding coefficient, I: Shannon index 
Different alleles were found with a low frequency $(\mathrm{F}<0.05)$ in the different strains. Rare alleles were not detected in strain 8 (Table 6).

Table 6

Frequency of rare alleles in the 10 Hungarian Bronze turkey hen strains

\begin{tabular}{|c|c|c|c|c|c|c|c|c|c|c|}
\hline \multirow[t]{2}{*}{ Locus } & \multirow[t]{2}{*}{ Alleles } & \multicolumn{7}{|c|}{ Alleles frequency in strains } & \multirow[b]{2}{*}{9} & \multirow[b]{2}{*}{10} \\
\hline & & 1 & 2 & 3 & 4 & 5 & 6 & 7 & & \\
\hline \multirow{2}{*}{ ADL0292 } & 117 & & & 0.042 & & & & & & \\
\hline & 131 & 0.039 & 0.036 & & & & 0.029 & & & \\
\hline ADL0149 & 224 & & & & & & & & 0.046 & \\
\hline MCW0080 & 279 & & & 0.050 & & & & 0.046 & & \\
\hline \multirow[t]{4}{*}{ MNT162 } & 81 & & & & & & & 0.031 & & \\
\hline & 86 & & & & & 0.033 & & & & \\
\hline & 88 & & & & 0.026 & & & & & \\
\hline & 91 & & 0.036 & & & & & & & \\
\hline \multirow[t]{2}{*}{ MNT197 } & 97 & & & & 0.026 & & & & & \\
\hline & 119 & & & & & 0.033 & & & & \\
\hline MNT199 & 152 & & 0.039 & & & & & & & 0.050 \\
\hline \multirow{2}{*}{ MNT214 } & 200 & & & 0.022 & & & & & & 0.050 \\
\hline & 192 & & & & & & & & & 0.050 \\
\hline \multirow[t]{2}{*}{ MNT327 } & 209 & 0.039 & & & & & & 0.031 & & 0.050 \\
\hline & 201 & & 0.036 & 0.021 & & & & & & \\
\hline \multirow[t]{2}{*}{ MNT106 } & 152 & & & & & 0.033 & & & & \\
\hline & 158 & & & & & 0.033 & & & & \\
\hline MNT332 & 150 & & & & & & & & 0.042 & 0.050 \\
\hline MNT387 & 145 & 0.039 & & & & 0.033 & & & & \\
\hline
\end{tabular}

$H_{\text {exp }}$ and $H_{\text {obs }}$ per strains ranged from $0.306 \pm 0.234$ (strain 1) to $0.434 \pm 0.238$ (strain 8) and from $0.311 \pm 0.210$ (strain 5) to $0.458 \pm 0.252$ (strain 8 ), respectively. Genetic diversity was highest in strain 8 (Table 5). $F_{\text {IS }}$ values were almost negative in all strains and ranged from 0.035 (strain 5) to -0.116 (strain 9).

Nei's unbiased genetic distance values were calculated (Table 7).

Table 7

Nei's unbiased genetic distances (below diagonal) between the Hungarian Bronze turkey hen strains

\begin{tabular}{lcccccccccc}
\hline & Strain 1 & Strain 2 & Strain 3 & Strain 4 & Strain 5 & Strain 6 & Strain 7 & Strain 8 & Strain 9 Strain 10 \\
\hline Strain 1 & 0.000 & & & & & & & & & \\
Strain 2 & 0.029 & 0.000 & & & & & & & & \\
Strain 3 & 0.047 & 0.020 & 0.000 & & & & & & & \\
Strain 4 & 0.018 & 0.012 & 0.017 & 0.000 & & & & & & \\
Strain 5 & 0.040 & 0.045 & 0.074 & 0.050 & 0.000 & & & & & \\
Strain 6 & 0.056 & 0.049 & 0.049 & 0.032 & 0.020 & 0.000 & & & & \\
Strain 7 & 0.081 & 0.063 & 0.067 & 0.074 & 0.059 & 0.068 & 0.000 & & & \\
Strain 8 & 0.026 & 0.032 & 0.038 & 0.022 & 0.015 & 0.011 & 0.028 & 0.000 & & \\
Strain 9 & 0.089 & 0.056 & 0.037 & 0.052 & 0.097 & 0.056 & 0.033 & 0.036 & 0.000 & \\
Strain 10 & 0.062 & 0.044 & 0.027 & 0.033 & 0.059 & 0.027 & 0.017 & 0.012 & 0.016 & 0.000 \\
\hline
\end{tabular}


The greatest distance values were found between the following pairs: strain $5 /$ strain 3 , strain $6 /$ strain 1 , strain $9 /$ strain 1 , strain $9 /$ strain 2 , strain $9 /$ strain 4 , strain $9 /$ strain 5 , strain $9 /$ strain 6, strain 10/strain 1 and strain 7/all other nine strains. Figure 1 shows the neighbour-joining dendrogram obtained using Nei's unbiased genetic distance values. The genetic relationship among strains is shown clearly.

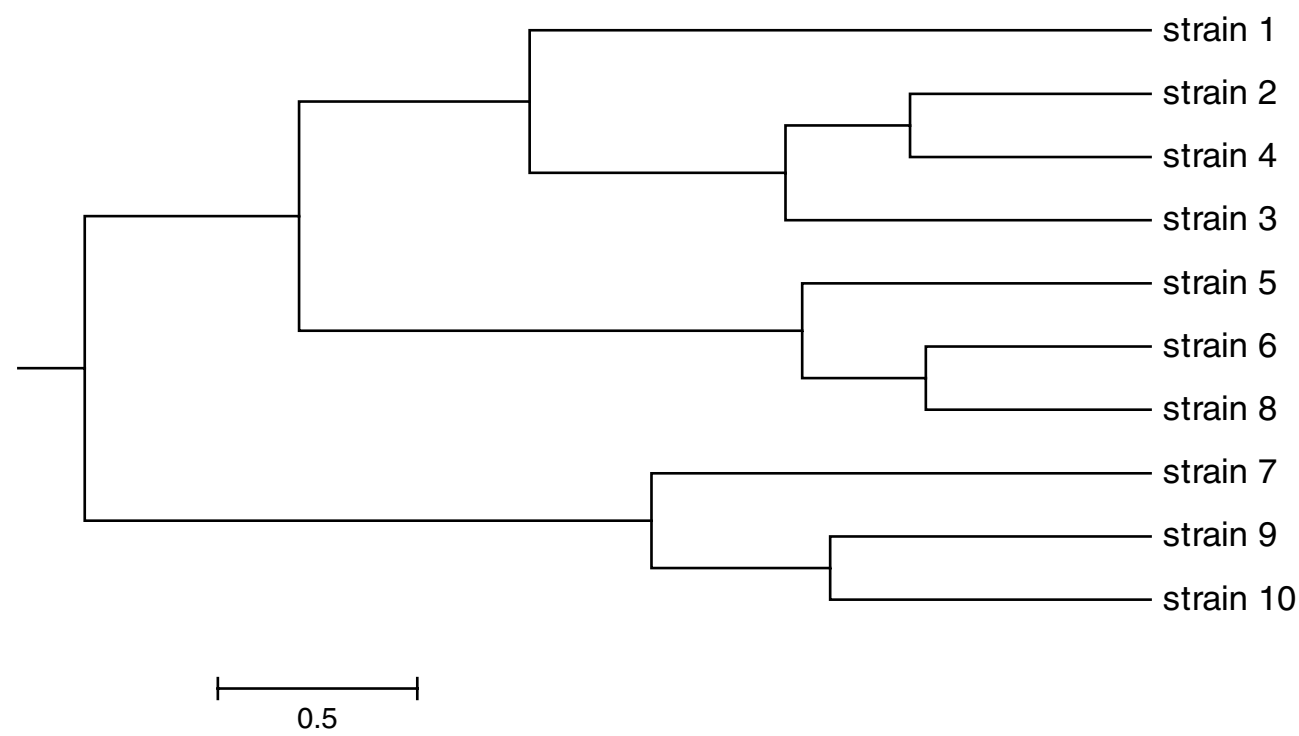

Figure 1

Neighbour-joining dendrogram among the Hungarian Bronze turkey hen strains

Genetic distance between the Hungarian Bronze turkey and Broad-breasted turkey strains

The mean number of observed alleles was lower $(2.769 \pm 1.013)$ and the mean number of effective alleles was higher $(1.952 \pm 0.738)$ in the Broad-breasted turkey than in the Hungarian Bronze turkey. Mean $\mathrm{H}_{\text {exp }}$ was higher than mean Hobs $(0.441 \pm 0.219$ and $0.419 \pm 0.232$, respectively) in the Broad-breasted turkey.

The result of $F_{\text {ST }}$ showed that $15.9 \%$ of the total genetic variation was explained by differences between the two strains, and the remaining $84.1 \%$ was accounted for differences among individuals. Nei's unbiased genetic distance values were calculated to determine the distance between the Hungarian Bronze and Broad-breasted turkey strains (Table 8).

Table 8

Genetic identity (above diagonal) and genetic distances (below diagonal) between the Hungarian Bronze turkey strains and Broad-breasted turkey

\begin{tabular}{lcc}
\hline & Hungarian Bronze turkey & Broad-breasted turkey \\
\hline Hungarian Bronze turkey & 0.000 & 0.745 \\
Broad-breasted turkey & 0.293 & 0.000 \\
\hline
\end{tabular}




\section{Discussion}

Microsatellite markers are now used efficiently for determining the genetic diversity of poultry species (Leberg et al. 1994, Rhodes et al. 1995, Ye et al. 1998, Kaiser et al. 2000, Romanov \& Weigend 2001, Kong et al. 2006, Tu et al. 2006, Shahbazi et al. 2007, Yan et al. 2008). In our study, 15 microsatellite markers were used to determine the genetic structure of a Hungarian Bronze turkey gene reserve population and its differences from the Broad-breasted turkey.

High numbers of alleles $(n=48)$ were found on the examined 15 loci in the Hungarian Bronze turkey. The use of a mixture of highly variable and less variable markers should reduce the danger of overestimating genetic variability, which might occur if only highly variable loci are used (Wimmers et al. 2000). In our study, all loci were polymorphic. The number of observed alleles per locus ranged from two to six, with a mean number of alleles of $3.2 \pm 1.1$, which demonstrates the utility of the chosen microsatellites as informative molecular markers in the examined breed. However, the effective number of allele was much lower than the observed alleles in all loci. Larger differences were found in cases of those microsatellites where rare alleles occurred because they are less likely to take part in mating. Altogether, 14 rare alleles were found on 10 loci. Szöke et al. (2004) previously studied this Hungarian Bronze turkey five generations earlier using seven microsatellites, from which five (ADL0292, ADL0293, ADL0149, ADL0266 and MCW0080) were the same as we have studied. They found one more allele on every locus except MCW0080, which means that one allele from each of these loci, was lost over the past five years. The frequency of these alleles was lower than 0.01 in their study. They assumed that gender greatly influences the probability of losing a rare allele using the present mating system, which was borne out by their simulation results. They reported that if only one hen had a rare allele from 144 turkeys (allele frequency less than 0.01 ), it was lost within five generations in $85.5 \%$ of the cases; when the male had the rare allele the value was only $21.5 \%$. We suppose that those lost alleles were carried by hens in the examined population. In the present study, 6 of the 14 rare alleles were carried only by hens, eight were found in both genders and one was observed only in bucks. The occurrence of the rare alleles among strains was different. Each allele was mainly observed only in one strain (Table 2). We should pay particular attention to the animals carrying the rare alleles because preservation requires more offspring from these animals during selection. However, this is difficult to put it into practice because turkeys have a short generational period and the cost of genotyping is expensive compared to their value.

Concerning heterozygosity, the mean $\mathrm{H}_{\text {exp }}$ and $\mathrm{H}_{\text {obs }}$ were not different $(0.392$ and 0.376 , respectively) in the overall population, with similar values obtained for both hens and bucks. Szöke et al. (2004) reported a mean $\mathrm{H}_{\text {exp }}$ of 0.165 and mean $\mathrm{H}_{\text {obs }}$ of 0.164 for seven loci in this strain. Differences in heterozygosity might be the result of different sample sizes and studied microsatellites. The $F_{15}$ and Shannon index indicated a low inbreeding within hens and bucks (Table 4). Multilocus $F_{S T}$ indicated that around $0.4 \%$ of the total genetic variation was explained by a sex difference; the remaining amount corresponded to differences among individuals. The $\mathrm{H}_{\exp }$ and $\mathrm{H}_{\text {obs }}$ varied marginally among hen strains, and $\mathrm{H}_{\text {obs }}$ was higher than $\mathrm{H}_{\text {exp }}$ in all strains except strain 5 . The highest heterozygosity was obtained in strain 8, which could be the reason for the absence of rare alleles. Kalinowski (2004) reported that rare alleles affect allelic richness. $F_{\text {IS }}$ and I also indicate similar high genetic diversities within all 
examined hen strains. All these results confirm that the genetic diversity in the Hungarian Bronze turkey has been preserved by the rotational mating system. Differences between the Hungarian Bronze turkey and Broad-breasted turkey were determined. Nei's unbiased values clearly indicated that the examined two populations were highly genetically differentiated because of their different breeding strategies.

We conclude that the present mating system is suitable for preserving the genetic diversity of the Hungarian Bronze turkey gene reserve population. However, genetic diversity could rapidly decrease by reducing the population size. Bottlenecks cause a rapid loss of rare alleles and also result in the loss of genetic variability because of the effects of genetic drift (Allendorf \& Luikart 2007). The Hungarian Bronze turkey population has a similar genetic diversity to other turkeys, suggesting that the studied population has not experienced serious genetic loss from the effects of bottlenecks. Inbreeding or breeding for a long time without fresh blood, especially in small populations, could reduce the level of genetic variability and produce a low heterozygosity value. Besides using the present breeding strategy, bringing fresh blood from other Bronze turkey populations is recommended. The results of this study might be useful as a guide for preserving the Hungarian Bronze turkey.

\section{Acknowledgements}

This work was financed by FVM AI0722/2007. Authors would like to thank the assistants at the farm of the University of Debrecen CASE for their help in collecting blood samples.

\section{References}

Allendorf FW, Luikart G (2007) Conservation and the Genetics of Populations. Blackwell Publishing, Malden USA, 642

Christman CJ, Hawes RO (1999) Birds of a Feather: Saving Rare Turkeys from Extinction. ALBC, Pittsboro, NC, USA

Kaiser MG, Yonash N, Cahaner A, Lamont SJ (2000) Microsatellite polymorphism between and within broiler populations. Poult Sci 79, 626-628

Kalinowski ST (2004) Counting alleles with rarefaction: private alleles and hierarchical sampling designs, Conserv Genet 5, 1-12

Kamara D, Gyenai KB, Geng T, Hammade H, Smith EJ (2007) Microsatellite marker-based genetic analysis of relatedness between commercial and heritage turkeys (Meleagris gallopavo). Poult Sci 86, 46-49

Kimura M, Crow JF (1964) The number of alleles that can be maintained in a finite population. Genetics 49, 725-738

Kong HS, Oh JD, Lee JH, Jo KJ, Sang BD, Choi CH, Kim SD, Lee SJ, Yeon SH, Jeon GJ, Lee HK (2006) Genetic variation and relationships of Korean native chickens and foreign breeds using 15 microsatellite markers. Asian Austral J Anim Sci 19, 1546-1550

Leberg PL, Stangel PW, Hillestad HO, Marchinton RL, Smith MH (1994) Genetic structure of reintroduced wild turkey and white-tailed deer populations. J Wildl Manage 58, 698-711

Levene H (1949) On a matching problem arising in genetics, Ann Math Stat 20, 91-94

Lewontin RC (1972) The apportionment of human diversity. BMC Evol Biol 6, 381-398

Mihók S, Bodó I, Bíró G, Süth M (1999) Meat production of the Bronze turkey reflected in addressing special consumer demands. Állattenyésztés és Takarmányozás. Hungarian J Anim Prod 48, 796-800 
Mihók S (2000) Bronze turkey. In: Bodó I (ed.), Living Heritage. Old Historical Hungarian Livestock. Agroinform Publishing and Printing Ltd., Budapest, Hungary, 84-85

Nei M (1987) Molecular Evolutionary Genetics. Columbia University Press, NY, USA

Rhodes OE, Buford DJ, Miller MS, Lutz RS (1995) Genetic structure of reintroduced Rio Grande wild turkeys in Kansas. J Wildl Manage 59, 771-775

Romanov MN, Weigend S (2001) Analysis of genetic relationships between various populations of domestic and jungle fowl using microsatellite markers. Poult Sci 80, 1057-1063

Shahbazi S, Mirhosseini SZ, Romanov MN (2007) Genetic diversity in five Iranian native chicken populations estimated by microsatellite markers. Biochem Genet 45, 63-75

Sütő Z (2006) Characterization of turkey breed. In: Mihók S (ed.) Economy animals-Breeds: Chicken, guinea fowl, turkey, duck, muscovy duck, goose. Mezőgazda Kiadó, 116-134 [in Hungarian]

Szalay IT, Kisné DDX, Virág Gy, Szentes K, Bódi L (2009) Prospects for conserving traditional poultry breeds in the Carpathian basin. Animal Welfare, Ethology and Housing Systems 5, 119-148 [in Hungarian]

Szöke Sz, Komlósi I, Korom E, Ispány M, Mihók S (2004) A statistical analysis of population variability in Bronze turkey considering gene conservation. Arch Tierz 47, 377-385

Tu YJ, Chen KW, Zhang SJ, Tang QP, Gao YS, Yang N (2006) Genetic diversity of 14 indigenous grey goose breeds in China based on microsatellite markers. Asian Austral J Anim Sci 19, 1-6

Weir BS, Cockerham CC (1984) Estimating F-statistics for the analysis of population structure. Evolution 38, 1358-1370

Wimmers K, Ponsuksili S, Hardge T, Valle-Zarate A, Mathur PK, Horst P (2000) Genetic distinctness of African, Asian and South American local chickens. Anim Genet 31, 159-165

Yan W, Liu XL, Hau SS, Wei H (2008) Study on genetic diversity of six duck populations with microsatellite DNA. Asian Austral J Anim Sci 21, 776-783

Ye X, Zhu J, Velleman G, Nestor KE (1998) Genetic diversity of commercial turkey primary breeding strain as estimated by DNA fingerprinting. Poult Sci 77, 802-807

Yeh FC, Yong R (1999) POPGENE version 1.31: Microsoft-based Freeware for Population Genetic Analysis. University of Alberta, Edmonton, Canada

Zsolnai A, Orbán L (1999) Accelerated separation of random complex DNA patterns in gels: comparing the performance of discontinuous and continuous buffers. Electrophor 7, 1462-1468

Received 2 September 2010, accepted 1 March 2011.

Corresponding author:

Sándor Mihók

email:mihok@agr.unideb.hu

Institute of Animal Sciences and Protection of Biodiversity, Centre for Agricultural and Applied Economic Sciences, University of Debrecen, Böszörményi str. 138, H-4032 Debrecen, Hungary 